Алена Ермакова

Гомель

\title{
Тэкст навін як тып дыскурсу
}

Вывучэнне мовы сродкаў масавай інфармацыі мае вялікую сацыяльную і палітычную значнасць. Якім чынам людзі набываюць сацыяльныя веды, як фарміруюцца іх погляды, устанойкі, як праз мову рэалізуюцца ідэалагічныя погляды? Агульнавядома, што вербальныя зносіны ўяўляюць сабой адзінства двух аспектаў - вербальнага інфармавання і вербальнага ӱздзеяння. Гэтае палажэнне імпліцытна сцвярджае актыўную ролю вытворцы тэкстаў і пасіўную іх спажыўца, што не зусім адпавядае сучаснаму разуменню асаблівасцяў дыскурсу навін.

Аналіз дыскурсу навін не абмяжоўваецца лінгвістычным апісаннем фаналагічных, марфалагічных, сінтаксічных або семантычных структур ізаляваных слой, словазлучэнняў або сказаў. Сучасныя падыходы да тэкстаў сродкаў масавай інфармацыі патрабуюць іншага разумення тэкстаў, як своеасаблівага тыпу дыскурсу ${ }^{1}$. Доўгі час дыскурс разумелі як звязную паслядойнасць сказаў, сёння ён трактуецца як складаная камунікатыўная з'ява, што ўключае акрамя вербальнай формы яшчэ і экстралінгвістычныя фактары, што спрыяюць разуменню тэксту. Веды пра свет, погляды, устаноўкі, мэты адрасата ўлічваюцца падчас прагматычнай інтэрпрэтацыі. Дыскурс з'яўляецца складаным адзінствам моўнай формы, значэнння і дзеяння. Таму найбольшую цікавасць уяўляе аналіз тэкстаў масавай інфармацыі з пазіцый дынамічнай прыроды іх вытворчасці, разумення і дзеяння, што рэалізуецца з іх да-

1 Т. А. ван Дейк, Язык. Познание. Коммуникация, Москва 1989, с. 111. 
памогай. У якасці вызначэння дыскурсу прымем ідэю Т. А. ван Дэйка аб узаемапранікненні тэксту і кантэксту, у аснове якой ідэя інтэртэкстуальнасці ${ }^{2}$. Дыскурс, які разумеецца як тэкст, пагружаны у сітуацыю зносін ${ }^{3}$, дапускае мноства вымярэнняў. 3 пазіцый прагмалінгвістыкі дыскурс уяўляе сабой інтэрактыўную дзейнасць удзельнікай зносін, абмен інфармацыяй, аказанне ўздзеяння адзін на аднаго, выкарыстанне розных камунікатыўных стратэгій, ix вербальнае і невербальнае ўвасабленне $\breve{y}$ практыцы зносін. Функцыянальны падыход прадугледжвае абумойленасць аналізу функцый дыскурсу вывучэннем функцый мовы ў шырокім сацыякультурным кантэксце. Лінгвастылістычны аналіз дыскурсу вылучае рэгістры зносін, размяжойвае вуснае і пісьмовае маўленне $\breve{y}$ іх жанравых разнавіднасцях, вывучае характарыстыкі функцыянальных стыляў. 3 пазіцыі фармальна або структурна арыентаванай лінгвістыкі дыскурс вызначаецца як мова, якая вышэй за ўзровень сказа або словазлучэння. Лінгвакультурнае вывучэнне дыскурсу вызначае спецыфіку зносін у межах пэўнага этнасу, вызначае формульныя мадэлі этыкету і маўленчых паводзін у цэлым ${ }^{4}$. Сацыялінгвістычны падыход да даследавання дыскурсу прадугледжвае аналіз удзельнікай зносін як прадстайнікой розных сацыяльных груп і аналіз умоў зносін у шырокім сацыякультурным кантэксце. Цікавасць да дыскурсу як кагнітыўна-семантычнай з'явы паўстала парайнальна нядайна. Любое камунікатыўнае дзеянне $\breve{y}$ межах спантаннага або арганізаванага дыскурсу ўяўляе сабой рэалізацыю тых ці іншых камунікатыўна-кагнітыўных структур. Такімі кагнітыўнымі структурамі з'яўляюцца фрэймавыя мадэлі, якія змяшчаюць інфармацыю сацыякультурнага характару. Фрэйм разглядаецца як адзін са спосабаў прадстайлення стэрэатыпнай сітуацыі, які змяшчае інфармацыю розных відаў. Вядомы галандскі лінгвіст Т.А ван Дэйк гаворыць пра тэрмін «фрэйм» у сувязі з арганізацыяй «агульных ведаў»у канцэптуальныя сістэмы. Рамкі разглядаюцца як адзінкі, арганізаваныя вакол нейкага канцэпта і ўтрымліваюць аснойную, тыповую і патэнцыйна магчымую інфармацыю, якая асацыіруецца з тым ці іншым канцэптам ${ }^{5}$.

2 Тамсама, с. 122.

3 Н. Д. Арутюнова, Дискурс, (в:) Лингвистический энциклопедический словарь, Москва 1990, с. 136-137.

4 В. И. Карасик, O munax дискурса, (в:) Языковая личность: институциональный и персональный дискурс, Волгоград 2000, с. 5-20.

5 Т. А. ван Дейк, Язык. Познание. Коммуникачия, Москва 1989, с. 16. 
Тэксты характарызуюцца складанымі асаблівасцямі, такімі як адносіны звязнасці паміж сказамі, агульная тэматычная структура, схематычная арганізацыя, шэрагам стылістычных і рытарычных параметрай.

На семантычным узройні аналіз дыскурсу як паслядоўнасці сказаў дае магчымасць вывучаць суаднесеныя адна 3 адной інтэрпрэтацыі: значэнні або рэферэнцыі слоў, несамастойных або самастойных сказаў разглядаюцца як функцыя ад значэнняй і рэферэнцый, замацаваных за папярэднімі сказамі. Гэты аспект дыскурсу часта апісваюць з пазіцый лакальнай або паслядоўнай кагерэнтнасці. Тэкст з'яўляецца семантычна звязаным, калі апісвае магчымую паслядоўнасць падзей, г.зн. семантычная звязнасць залежыць ад нашых ведаў і ўяўленняў аб тым, што магчыма ў гэтым свеце.

Наступны, больш высокі і глабальны, узровень аналізу дыскурсу сродкай масавай інфармацыі - семантычная макраструктура ${ }^{6}$. Семантычная макраструктура выяўляецца у працэсе вылучэння топікаў з тэкстаў. Тэорыя макраструктур дае магчымасць даследаваць асаблівыя характарыстыкі загалоўка і ліда, у якіх суб'ектыўна абагульняецца астатняя частка паведамлення. Вылучэнне макраструктур тлумачыць, чаму ў памяці чытачоў утрымліваюцца толькі асноўныя топікі, г. зн. вышэйшыя ўзроўні семантычнай макраструктуры тэкстаў навін.

Схематычная суперструктура ${ }^{7}$ тэкстаў навін з'яўляецца той формай, што арганізуе агульнае значэнне тэксту як цэлага. Схема гэта зададзена наборам характэрных катэгорый і правіл, што вызначаюць ix паслядойнасць. Газетныя паведамленні штодзённа публікуюцца тысячамі і яны арганізаваны ў адпаведнасці з такой схемай, схемай навін. Корпус тэксту дэманструе такія катэгорыі, як кароткі змест, галоўная падзея, фон, кантэкст, гісторыя, вербальныя рэакцыі, каментар.

Арлен Кашкурэвіч не згодзен з Мачісам

У Светлагорскай кариіннай галерэі “Традыцьия" імя Германа Пранішнікава адкрыта персанальная выстава народнага мастака Беларусі Арлена Кашкурэвіча. (Загаловак і лід - кароткі змест, галоўная падзея). Асаблівыя ўмовы вытворчасці і ўспрымання навін патрабуюць з'яўлення важнай інфармацыі ў пачатку тэксту. Структурыраванне па прынцыпу рэлевантнасці пранізвае ӱвесь тэкст навін.

\footnotetext{
6 Tамсама, с. 129.

7 Tамсама, c. 130.
} 
Усе 26 яго графічных твораў, прадстаўленьх на выставе, робяиь нас пэўньм чьлнам яго сааўтарамі, аднадумцамі. Яньи прасякнуты глыбінным адчуваннем нашай драматычнай гісторыі, філасофскім асэнсаваннем не толькі мінулага, але $і$ сучаснага жыция. Такое адчуваеича нават у серьі, так $i$ хочачиа сказачь, замалёвак з натуры "Гэтае мілае гарадское жьичё...", але самі творы адразу ж выляўляючь іранічнасць падтэксту назвы чыкла. Не такім ужо мільм аказваечиа гэтае жыциё, калі разглядаеш кариінь "Людзі у тумане", "Мьи толькі прахожыя", "Сабачая плячоўка", "Сустрэча", "Сон старога музыканта". Толькі зрокавага ўспрымання для іх вельмі і вельмі мала. Вачьма пачынае глядзечь душа... (Кантэкст)

Арлен Кашкурэвіч вядомьи, перш за ўсё, графічнымі серыямі "Партызаны", "Купаліяна", "Асветнікі", "Святыя зямлі беларускай", "Прысвячэнне В. Быкаву"... ён з пранікнёнай таленавітасцю аздобіу многія кнігі, у тылм ліку "Курган" Янкі Купаль, "Песню пра зубра" Міколь Гусоўскага, "Каласьи пад сярпом тваім" Уладзіміра Караткевіча, "Снежныя зімь" Івана Шамякіна, "Хатьискую аповесць" Алеся Адамовіча (Гісторыя).

Светлагориь маючь рэдкасную магчымасиь пабачьиь прасякнутую гістарычнай веліччу яго кариіну "Паляванне ў Вялікім княстве Літоўскім" і славуты трыпиіх "У часы Ірада" (Галоўная падзея). Спецыфічнай асаблівасцю тэкстаў навін з'яўляеца тое, што і топікі i схема навін, што арганізуе ix, не прадстаўлены у тэксце адной лінейнай паслядойнасцю. Яны дыскрэтныя, з'яўляюцца ў тэксце па частках.

Як прызнаўся Арлен Кашкуровіч, ён не згодзен з Анры Мачісам, які нібыта аднойчь зайважьіў, што хацеў бы, каб яго творы былі для гледачоў чымсьчі накшталт утульньхх крэслаў. "Для мяне важна, каб мае кариінь, наадварот, перашкаджалі гэтай уяўнай утульнасиі, заклікалі да эмачьянальнага роздуму", - гаворыць Арлен Міхайлавіч (Вербальная рэакцыя). ("Гомельская праўда", 20.11.2010)

Макраструктуры выводзяцца 3 тэкстаў на аснове нашых ведаў і перакананняў, і таму яны вар'іруюцца.

Тэматычная структура тэксту разгортваецца паслядоўна, кожны абзац "згортваецца" у топік.

1. Персанальная выстава Арлена Кашкуровіча

2. 26 твораў - філасофскае адчуванне жыция

3. Арлен Кашкуровіч вядомь

4. Светлагориы маючь магчьлмасць пабачьць карчінь

5. Кариінь не уттульныля крэсль, яны заклікаючь да эмаџылянальнага роздуму 
Топікі лёгка згортваюцца ў адзін, які фармулюем у якасці загалойка: Арлен Кашкурэвіч не згодзен з Мачісам (які лічыць, што карціны - утульныя крэслы)

У тэкст актыўна "ўводзіцца" чытач, што дасягаецца "рэпартажнымі прыёмамі": калі разглядаеш кариінь; такое адиуваеича (чытач бачыць вачыма аўтара), аўтар аб'яднойвае чытача і сябе: робячь нас пэўным чынам яго саауттарамі, аднадумчамі, у тэксце сфарміравана выразнае поле суб'ектыўнай мадальнасці: прасякнуты гльбінным адчуваннем, так $і$ хочачча сказачь, вачьма пачынае глядзець душа, маючь рэдкасную магчымасць, прасякнутую гістарычнай веліччу, славуты трыпиіх. Выразная ацэначнасць сфарміравана пераважна сродкамі лексічнага ўзройню.

Тэкст тэматычна дакладны, схематычная суперструктура, мікраі макраструктурная арганізацыя правільныя. Тэкст лёгка ўспрымаецца і з поспехам выконвае асноўныя задачы: інфармуе і ўздзейнічае (заклікае да эмаиьлянальнага роздуму) шляхам эмацыянальнага заражэння, заклікае да дзеяння (хачу наведаць выставу!).

Высветліць прычыны з'яўлення зместу - важная задача ў працэсе вывучэння дыскурса навін. Актуалізацыя таго ці іншага зместу мае прычынна-выніковую аснову.

Як слушна заўважае I. Ухванава-Шмыгава ${ }^{8}$ кантэнт і кантэкст узаемна праяўляюцца адзін у другім. Кантэнт - гэта фокус увагі, а кантэкст - яго фрэйм, рамка (якая часам не ўспрымаецца, але вызначае і фарміруе кантэнт). Каб актуалізаваць шматзначнасць тэкстаў, неабходна ўмець кіраваць “фокусам увагі". Кантэнт можа фарміраваць стэрэатып. I як паказвае практыка, стэрэатыпізацыя - актыўны прыём моўнага ўздзеяння ў сродках масавай камунікацыі.

Ацэначны стэрэатып складаюць аб'екты, што ўваходзяць у класіфікацыйныя структуры і валодаюць стандартным наборам прыкмет. На аб'ект маўлення накладваюцца ӱзоры і стандарты, яго суадносяць са шкалой ацэнак. Уяўленне пра стэрэатып з'яўляецца імпліцытным, яно - псіхалінгвістычная аснова выказвання. Соцыум, ствараючы карціну свету, мае пастаяннае ўяўленне пра аб'екты, вызначае іх праз паняцці, падкрэсліваючы сутнасць (інтэнсіянал тэрміна). Мадэль свету ўяўляе сабой пэўным чынам арганізаваныя веды аб свеце, якія характэрныя кагнітыўнай сістэме або яе мадэлі. Гэтую мадэль ствараюць

8 И. Ф. Ухванова-Шмыгова, Причинно-генетическое моделирование плана содержания текста как основа для структурирования его контекстной информачии, (в:) Тезисы научн. докл. и сообщений, Ижевск 1992, с. 10-27. 
“аб'ектыўныя" веды (агульныя веды пра свет) і “суб'ектыўныя". Гэта каштоўнасці і іх іерархіi, семантычныя канструкты тыпу "норма", "каузіраванне" і іншыя кагнітыўныя структуры, што абагульняюць вопыт індывіда і соцыума.

Стэрэатыпы фарміруюцца на аснове асацыятыўных сувязей па мадэлі “А мае адносіны да В", дзе В - адзін з прататыпічных канцэптаў, што выступае сімвалам дабра / зла.

3 аднаго боку, ён з'яўляецца найкарацейшым шляхам да чытача па прычыне яго агульнадаступнасці, з другога - пераасэнсаванне стэрэатыпу можа быць сродкам актуалізацыі новага зместу і значным фактарам уздзеяння.

Калі чытач умее распазнаваць тэксты, якія аказваюць агрэсіўнае ўздзеянне, магчыма апрацойка тэкстаў пры дапамозе контрсцэнарыяў. Ён пачынае шукаць алагізмы ў тэксце або проста палохаецца ўздзеяння і адмаўляецца ад чытання. Названыя механізмы непажаданыя для аўтара тэксту. Каб пазбегнуць іх рэалізацыі, аўтар можа трансліраваць тэкст у імпліцытнай форме, выкарыстойваючы сродкі намінацыі, рэферэнцыі, сінтаксічныя прыёмы або скарыстаць стэрэатып, фрагмент канцэптуальнай карціны свету, устойлівае культурна-нацыянальнае ўяўленне. Гэтыя ўпарадкаваныя, схематычныя, дэтэрмінаваныя культурай "вобразы свету" эканомяць намаганні чалавека падчас успрымання складаных аб'ектаў свету. Апошні прыём з'яўляецца вельмі дзейсным, бо стэрэатып выконвае шэраг кагнітыўных функцый функцыю схематызацыі і спрашчэння, функцыю фарміравання і захавання групавой ідэалогіі.

Рэпрэзентацыя і ўзнаўленне падзей-навін журналістамі - не такі просты і інертны працэс. Сёння у перыяд глабалізацыі праблема эфектыўнай камунікацыі як ніколі актуальная. СМI даюць рэальную практыку маўлення, якое выходзіць у прастору жывой камунікацыі, узаемадзеяння.

\section{S T R E S Z Z E N I E}

\section{TEKST WIADOMOŚCI JAKO TYP DYSKURSU}

Artykuł analizuje poziomy tekstu w mass mediach. Współczesne podejścia do tekstów masowego przekazu zakładają konieczność traktowania każdego z nich jako specyficznego rodzaju dyskursu. Dyskurs to jedność formy językowej, znaczenia i działania. Stąd ogromne zainteresowanie analizą tekstów medialnych z perspektywy dynamicznego charakteru ich tworzenia. Teksty dziennikarskie jako oddzielny 
typ dyskursu społecznego stanowią skomplikowaną konstrukcję formy, związanego z nią znaczenia i działania, które może być wynikiem zastosowania odpowiednich środków tekstowych. Analiza gramatyczna języka w tekstach prasowych pozwala wskazać ogólną orientację informacji przekazywanej przez dziennikarza lub informację całego wydania.

Słowa kluczowe: dyskurs, ogólne ramy, struktura semantyczna, mikrostruktura, stereotyp ewaluacyjny.

\section{S U M M A R Y}

\section{THE TEXT OF THE NEWS AS A TYPE OF DISCOURSE}

The article examines the levels of analysis of mass media texts. Modern approaches to dealing with mass media texts require considering texts as a particular type of discourse. Discourse is a complex unity of linguistic form, meaning and action. Therefore, the greatest interest lies in the analysis of mass media texts from the perspective of dynamic nature of their production, understanding and action implemented by their means. The journalistic text as a distinctive type of social discourse is a complex unity of linguistic form, meaning inherent in this form, and action which can be caused by means of this text. The grammatical analysis of language in press is capable of revealing the general orientation of a journalist's message or the message of the whole edition.

Key words: discourse, frame, semantic structure, macrostructure, evaluating stereotype. 